\title{
Masalah Pendidikan di Indonesia Oleh
}

\author{
Andi Agustang \\ andi.agustang@unm.ac.id \\ Indah Ainun Mutiara \\ indahainun@unismuh.ac.id \\ Andi Asrifan \\ andiasrifan@gmail.com
}

\section{Latar Belakang Masalah}

Kualitas pendidikan di Indonesia saat ini sangat memprihatinkan. Ini dibuktikan antara lain dengan data UNESCO (2000) tentang peringkat Indeks Pengembangan Manusia (Human Development Index), yaitu komposisi dari peringkat pencapaian pendidikan, kesehatan, dan penghasilan per kepala yang menunjukkan, bahwa indeks pengembangan manusia Indonesia makin menurun. Di antara 174 negara di dunia, Indonesia menempati urutan ke-102 (1996), ke-99 (1997), ke-105 (1998), dan ke-109 (1999).

Menurut survei Political and Economic Risk Consultant (PERC), kualitas pendidikan di Indonesia berada pada urutan ke-12 dari 12 negara di Asia. Posisi Indonesia berada di bawah Vietnam. Data yang dilaporkan The World Economic Forum Swedia (2000), Indonesia memiliki daya saing yang rendah, yaitu hanya menduduki urutan ke-37 dari 57 negara yang disurvei di dunia. Dan masih menurut survai dari lembaga yang sama Indonesia hanya berpredikat sebagai follower bukan sebagai pemimpin teknologi dari 53 negara di dunia.

Memasuki abad ke- 21 dunia pendidikan di Indonesia menjadi heboh. Kehebohan tersebut bukan disebabkan oleh kehebatan mutu pendidikan nasional tetapi lebih banyak disebabkan karena kesadaran akan bahaya keterbelakangan pendidikan di Indonesia. Perasan ini disebabkan karena beberapa hal yang mendasar.

Salah satunya adalah memasuki abad ke- 21 gelombang globalisasi dirasakan kuat dan terbuka. Kemajaun teknologi dan perubahan yang terjadi memberikan kesadaran baru bahwa Indonesia tidak lagi berdiri sendiri. Indonesia berada di tengah-tengah dunia yang baru, dunia terbuka sehingga orang bebas membandingkan kehidupan dengan negara lain.

Yang kita rasakan sekarang adalah adanya ketertinggalan didalam mutu pendidikan. Baik pendidikan formal maupun informal. Dan hasil itu diperoleh setelah kita membandingkannya dengan negara lain. Pendidikan memang telah menjadi penopang dalam meningkatkan sumber daya manusia Indonesia untuk pembangunan bangsa. Oleh karena itu, kita seharusnya dapat meningkatkan sumber daya manusia Indonesia yang tidak kalah bersaing dengan sumber daya manusia di negara-negara lain. 
Setelah kita amati, nampak jelas bahwa masalah yang serius dalam peningkatan mutu pendidikan di Indonesia adalah rendahnya mutu pendidikan di berbagai jenjang pendidikan, baik pendidikan formal maupun informal. Dan hal itulah yang menyebabkan rendahnya mutu pendidikan yang menghambat penyediaan sumber daya menusia yang mempunyai keahlian dan keterampilan untuk memenuhi pembangunan bangsa di berbagai bidang.

Kualitas pendidikan Indonesia yang rendah itu juga ditunjukkan data Balitbang (2003) bahwa dari 146.052 SD di Indonesia ternyata hanya delapan sekolah saja yang mendapat pengakuan dunia dalam kategori The Primary Years Program (PYP). Dari 20.918 SMP di Indonesia ternyata juga hanya delapan sekolah yang mendapat pengakuan dunia dalam kategori The Middle Years Program (MYP) dan dari 8.036 SMA ternyata hanya tujuh sekolah saja yang mendapat pengakuan dunia dalam kategori The Diploma Program (DP).

Penyebab rendahnya mutu pendidikan di Indonesia antara lain adalah masalah efektifitas, efisiensi dan standardisasi pengajaran. Hal tersebut masih menjadi masalah pendidikan di Indonesia pada umumnya. Adapun permasalahan khusus dalam dunia pendidikan yaitu:

(1). Rendahnya sarana fisik,

(2). Rendahnya kualitas guru,

(3). Rendahnya kesejahteraan guru,

(4). Rendahnya prestasi siswa,

(5). Rendahnya kesempatan pemerataan pendidikan,

(6). Rendahnya relevansi pendidikan dengan kebutuhan,

(7). Mahalnya biaya pendidikan.

Permasalahan-permasalahan yang tersebut di atas akan menjadi bahan bahasan dalam makalah yang berjudul "Masalah Pendidikan di Indonesia" ini.

\section{Ciri-ciri Pendidikan di Indonesia}

Cara melaksanakan pendidikan di Indonesia sudah tentu tidak terlepas dari tujuan pendidikan di Indonesia, sebab pendidikan Indonesia yang dimaksud di sini ialah pendidikan yang dilakukan di bumi Indonesia untuk kepentingan bangsa Indonesia.

Aspek ketuhanan sudah dikembangkan dengan banyak cara seperti melalui pendidikan-pendidikan agama di sekolah maupun di perguruan tinggi, melalui ceramah-ceramah agama di masyarakat, melalui kehidupan beragama di asramaasrama, lewat mimbar-mimbar agama dan ketuhanan di televisi, melalui radio, surat kabar dan sebagainya. Bahan-bahan yang diserap melalui media itu akan berintegrasi dalam rohani para siswa/mahasiswa.

Pengembangan pikiran sebagian besar dilakukan di sekolah-sekolah atau perguruan-perguruan tinggi melalui bidang studi-bidang studi yang mereka 
pelajari. Pikiran para siswa/mahasiswa diasah melalui pemecahan soal-soal, pemecahan berbagai masalah, menganalisis sesuatu serta menyimpulkannya.

\section{Kualitas Pendidikan di Indonesia}

Seperti yang telah kita ketahui, kualitas pendidikan di Indonesia semakin memburuk. Hal ini terbukti dari kualitas guru, sarana belajar, dan muridmuridnya. Guru-guru tentuya punya harapan terpendam yang tidak dapat mereka sampaikan kepada siswanya. Memang, guru-guru saat ini kurang kompeten. Banyak orang yang menjadi guru karena tidak diterima di jurusan lain atau kekurangan dana. Kecuali guru-guru lama yang sudah lama mendedikasikan dirinya menjadi guru. Selain berpengalaman mengajar murid, mereka memiliki pengalaman yang dalam mengenai pelajaran yang mereka ajarkan. Belum lagi masalah gaji guru. Jika fenomena ini dibiarkan berlanjut, tidak lama lagi pendidikan di Indonesia akan hancur mengingat banyak guru-guru berpengalaman yang pensiun.

Sarana pembelajaran juga turut menjadi faktor semakin terpuruknya pendidikan di Indonesia, terutama bagi penduduk di daerah terbelakang. Namun, bagi penduduk di daerah terbelakang tersebut, yang terpenting adalah ilmu terapan yang benarbenar dipakai buat hidup dan kerja. Ada banyak masalah yang menyebabkan mereka tidak belajar secara normal seperti kebanyakan siswa pada umumnya, antara lain guru dan sekolah.

"Pendidikan ini menjadi tanggung jawab pemerintah sepenuhnya," kata Presiden Susilo Bambang Yudhoyono usai rapat kabinet terbatas di Gedung Depdiknas, J1 Jenderal Sudirman, Jakarta, Senin (12/3/2007).

Presiden memaparkan beberapa langkah yang akan dilakukan oleh pemerintah dalam rangka meningkatkan kualitas pendidikan di Indonesia, antara lain yaitu:

- Langkah pertama yang akan dilakukan pemerintah, yakni meningkatkan akses terhadap masyarakat untuk bisa menikmati pendidikan di Indonesia. Tolak ukurnya dari angka partisipasi.

- Langkah kedua, menghilangkan ketidakmerataan dalam akses pendidikan, seperti ketidakmerataan di desa dan kota, serta jender.

- Langkah ketiga, meningkatkan mutu pendidikan dengan meningkatkan kualifikasi guru dan dosen, serta meningkatkan nilai rata-rata kelulusan dalam ujian nasional.

- Langkah keempat, pemerintah akan menambah jumlah jenis pendidikan di bidang kompetensi atau profesi sekolah kejuruan. Untuk menyiapkan tenaga siap pakai yang dibutuhkan.

- Langkah kelima, pemerintah berencana membangun infrastruktur seperti menambah jumlah komputer dan perpustakaan di sekolah-sekolah.

- Langkah keenam, pemerintah juga meningkatkan anggaran pendidikan. Untuk tahun ini dianggarkan Rp 44 triliun.

- Langkah ketujuh, adalah penggunaan teknologi informasi dalam aplikasi pendidikan. 
- Langkah terakhir, pembiayaan bagi masyarakat miskin untuk bisa menikmati fasilitas penddikan.

\section{Penyebab Rendahnya Kualitas Pendidikan di Indonesia}

Di bawah ini akan diuraikan beberapa penyebab rendahnya kualitas pendidikan di Indonesia secara umum, yaitu:

\section{Efektifitas Pendidikan Di Indonesia}

Pendidikan yang efektif adalah suatu pendidikan yang memungkinkan peserta didik untuk dapat belajar dengan mudah, menyenangkan dan dapat tercapai tujuan sesuai dengan yang diharapkan. Dengan demikian, pendidik (dosen, guru, instruktur, dan trainer) dituntut untuk dapat meningkatkan keefektifan pembelajaran agar pembelajaran tersebut dapat berguna.

Efektifitas pendidikan di Indonesia sangat rendah. Setelah praktisi pendidikan melakukan penelitian dan survey ke lapangan, salah satu penyebabnya adalah tidak adanya tujuan pendidikan yang jelas sebelm kegiatan pembelajaran dilaksanakan. Hal ini menyebabkan peserta didik dan pendidik tidak tahu "goal" apa yang akan dihasilkan sehingga tidak mempunyai gambaran yang jelas dalam proses pendidikan. Jelas hal ini merupakan masalah terpenting jika kita menginginkan efektifitas pengajaran. Bagaimana mungkin tujuan akan tercapai jika kita tidak tahu apa tujuan kita.

Selama ini, banyak pendapat beranggapan bahwa pendidikan formal dinilai hanya menjadi formalitas saja untuk membentuk sumber daya manusia Indonesia. Tidak perduli bagaimana hasil pembelajaran formal tersebut, yang terpenting adalah telah melaksanakan pendidikan di jenjang yang tinggi dan dapat dianggap hebat oleh masyarakat. Anggapan seperti itu jugalah yang menyebabkan efektifitas pengajaran di Indonesia sangat rendah. Setiap orang mempunyai kelebihan dibidangnya masing-masing dan diharapkan dapat mengambil pendidikaan sesuai bakat dan minatnya bukan hanya untuk dianggap hebat oleh orang lain.

Dalam pendidikan di sekolah menegah misalnya, seseorang yang mempunyai kelebihan dibidang sosial dan dipaksa mengikuti program studi IPA akan menghasilkan efektifitas pengajaran yang lebih rendah jika dibandingkan peserta didik yang mengikuti program studi yang sesuai dengan bakat dan minatnya. Halhal sepeti itulah yang banyak terjadi di Indonesia. Dan sayangnya masalah gengsi tidak kalah pentingnya dalam menyebabkan rendahnya efektifitas pendidikan di Indonesia.

\section{Efisiensi Pengajaran Di Indonesia}

Efisien adalah bagaimana menghasilkan efektifitas dari suatu tujuan dengan proses yang lebih 'murah'. Dalam proses pendidikan akan jauh lebih baik jika kita memperhitungkan untuk memperoleh hasil yang baik tanpa melupakan proses yang baik pula. Hal-hal itu jugalah yang kurang jika kita lihat pendidikan di Indonesia. Kita kurang mempertimbangkan prosesnya, hanya bagaimana dapat meraih standar hasil yang telah disepakati. 
Beberapa masalah efisiensi pengajaran di dindonesia adalah mahalnya biaya pendidikan, waktu yang digunakan dalam proses pendidikan, mutu pegajar dan banyak hal lain yang menyebabkan kurang efisiennya proses pendidikan di Indonesia. Yang juga berpengaruh dalam peningkatan sumber daya manusia Indonesia yang lebih baik.

Masalah mahalnya biaya pendidikan di Indonesia sudah menjadi rahasia umum bagi kita. Sebenarnya harga pendidikan di Indonesia relative lebih randah jika kita bandingkan dengan Negara lain yang tidak mengambil sitem free cost education. Namun mengapa kita menganggap pendidikan di Indonesia cukup mahal? Hal itu tidak kami kemukakan di sini jika penghasilan rakyat Indonesia cukup tinggi dan sepadan untuk biaya pendidiakan.

Jika kita berbicara tentang biaya pendidikan, kita tidak hanya berbicara tenang biaya sekolah, training, kursus atau lembaga pendidikan formal atau informal lain yang dipilih, namun kita juga berbicara tentang properti pendukung seperti buku, dan berbicara tentang biaya transportasi yang ditempuh untuk dapat sampai ke lembaga pengajaran yang kita pilih. Di sekolah dasar negeri, memang benar jika sudah diberlakukan pembebasan biaya pengajaran, nemun peserta didik tidak hanya itu saja, kebutuhan lainnya adalah buku teks pengajaran, alat tulis, seragam dan lain sebagainya yang ketika kami survey, hal itu diwajibkan oleh pendidik yang berssngkutan. Yang mengejutkanya lagi, ada pendidik yang mewajibkan les kepada peserta didiknya, yang tentu dengan bayaran untuk pendidik tersebut.

Selain masalah mahalnya biaya pendidikan di Indonesia, masalah lainnya adalah waktu pengajaran. Dengan survey lapangan, dapat kita lihat bahwa pendidikan tatap muka di Indonesia relative lebih lama jika dibandingkan negara lain. Dalam pendidikan formal di sekolah menengah misalnya, ada sekolah yang jadwal pengajarnnya perhari dimulai dari pukul 07.00 dan diakhiri sampai pukul 16.00.. Hal tersebut jelas tidak efisien, karena ketika kami amati lagi, peserta didik yang mengikuti proses pendidikan formal yang menghabiskan banyak waktu tersebut, banyak peserta didik yang mengikuti lembaga pendidikan informal lain seperti les akademis, bahasa, dan sebagainya. Jelas juga terlihat, bahwa proses pendidikan yang lama tersebut tidak efektif juga, karena peserta didik akhirnya mengikuti pendidikan informal untuk melengkapi pendidikan formal yang dinilai kurang.

Selain itu, masalah lain efisiensi pengajaran yang akan kami bahas adalah mutu pengajar. Kurangnya mutu pengajar jugalah yang menyebabkan peserta didik kurang mencapai hasil yang diharapkan dan akhirnya mengambil pendidikan tambahan yang juga membutuhkan uang lebih.

Yang kami lihat, kurangnya mutu pengajar disebabkan oleh pengajar yang mengajar tidak pada kompetensinya. Misalnya saja, pengajar A mempunyai dasar pendidikan di bidang bahasa, namun di mengajarkan keterampilan, yang sebenarnya bukan kompetensinya. Hal-tersebut benar-benar terjadi jika kita melihat kondisi pendidikan di lapangan yang sebanarnya. Hal lain adalah pendidik 
tidak dapat mengomunikasikan bahan pengajaran dengan baik, sehingga mudah dimengerti dan menbuat tertarik peserta didik.

Sistem pendidikan yang baik juga berperan penting dalam meningkatkan efisiensi pendidikan di Indonesia. Sangat disayangkan juga sistem pendidikan kita berubah-ubah sehingga membingungkan pendidik dan peserta didik.

Dalam beberapa tahun belakangan ini, kita menggunakan sistem pendidikan kurikulum 1994, kurikulum 2004, kurikulum berbasis kompetensi yang pengubah proses pengajaran menjadi proses pendidikan aktif, hingga kurikulum baru lainnya. Ketika mengganti kurikulum, kita juga mengganti cara pendidikan pengajar, dan pengajar harus diberi pelatihan terlebih dahulu yang juga menambah cost biaya pendidikan. Sehingga amat disayangkan jika terlalu sering mengganti kurikulum yang dianggap kuaran efektif lalu langsung menggantinya dengan kurikulum yang dinilai lebih efektif.

Konsep efisiensi akan tercipta jika keluaran yang diinginkan dapat dihasilkan secara optimal dengan hanya masukan yang relative tetap, atau jika masukan yang sekecil mungkin dapat menghasilkan keluaran yang optimal. Konsep efisiensi sendiri terdiri dari efisiensi teknologis dan efisiensi ekonomis. Efisiensi teknologis diterapkan dalam pencapaian kuantitas keluaran secara fisik sesuai dengan ukuran hasil yang sudah ditetapkan. Sementara efisiensi ekonomis tercipta jika ukuran nilai kepuasan atau harga sudah diterapkan terhadap keluaran.

Konsep efisiensi selalu dikaitkan dengan efektivitas. Efektivitas merupakan bagian dari konsep efisiensi karena tingkat efektivitas berkaitan erat dengan pencapaian tujuan relative terhadap harganya. Apabila dikaitkan dengan dunia pendidikan, maka suatu program pendidikan yang efisien cenderung ditandai dengan pola penyebaran dan pendayagunaansumber-sumber pendidikan yang sudah ditata secara efisien. Program pendidikan yang efisien adalah program yang mampu menciptakan keseimbangan antara penyediaan dan kebutuhan akan sumber-sumber pendidikan sehingga upaya pencapaian tujuan tidak mengalami hambatan.

\section{Standardisasi Pendidikan Di Indonesia}

Jika kita ingin meningkatkan mutu pendidikan di Indonesia, kita juga berbicara tentang standardisasi pengajaran yang kita ambil. Tentunya setelah melewati proses untuk menentukan standar yang akan diambil.

Dunia pendidikan terus berudah. Kompetensi yang dibutuhka oleh masyarakat terus-menertus berunah apalagi di dalam dunia terbuka yaitu di dalam dunia modern dalam ere globalisasi. Kompetendi-kompetensi yang harus dimiliki oleh seseorang dalam lembaga pendidikan haruslah memenuhi standar. 
Seperti yang kita lihat sekarang ini, standar dan kompetensi dalam pendidikan formal maupun informal terlihat hanya keranjingan terhadap standar dan kompetensi. Kualitas pendidikan diukur oleh standard an kompetensi di dalam berbagai versi, demikian pula sehingga dibentuk badan-badan baru untuk melaksanakan standardisasi dan kompetensi tersebut seperti Badan Standardisasi Nasional Pendidikan (BSNP).

Tinjauan terhadap standardisasi dan kompetensi untuk meningkatkan mutu pendidikan akhirnya membawa kami dalam pengunkapan adanya bahaya yang tersembunyi yaitu kemungkinan adanya pendidikan yang terkekung oleh standar kompetensi saja sehngga kehilangan makna dan tujuan pendidikan tersebut.

Peserta didik Indonesia terkadang hanya memikirkan bagaiman agar mencapai standar pendidikan saja, bukan bagaimana agar pendidikan yang diambil efektif dan dapat digunakan. Tidak perduli bagaimana cara agar memperoleh hasil atau lebih spesifiknya nilai yang diperoleh, yang terpentinga adalah memenuhi nilai di atas standar saja.

Hal seperti di atas sangat disayangkan karena berarti pendidikan seperti kehilangan makna saja karena terlalu menuntun standar kompetensi. Hal itu jelas salah satu penyebab rendahnya mutu pendidikan di Indonesia.

Selain itu, akan lebih baik jika kita mempertanyakan kembali apakah standar pendidikan di Indonesia sudah sesuai atau belum. Dalam kasus UAN yang hampir selalu menjadi kontrofesi misalnya. Kami menilai adanya sistem evaluasi seperti UAN sudah cukup baik, namun yang kami sayangkan adalah evaluasi pendidikan seperti itu yang menentukan lulus tidaknya peserta didik mengikuti pendidikan, hanya dilaksanakan sekali saja tanpa melihat proses yang dilalu peserta didik yang telah menenpuh proses pendidikan selama beberapa tahun. Selain hanya berlanhsug sekali, evaluasi seperti itu hanya mengevaluasi 3 bidang studi saja tanpa mengevaluasi bidang studi lain yang telah didikuti oleh peserta didik.

Banyak hal lain juga yang sebenarnya dapat kami bahas dalam pembahasan sandardisasi pengajaran di Indonesia. Juga permasalahan yang ada di dalamnya, yang tentu lebih banyak, dan membutuhkan penelitian yang lebih dalam lagi

Penyebab rendahnya mutu pendidikan di Indonesia juga tentu tidah hanya sebatas yang kami bahas di atas. Banyak hal yang menyebabkan rendahnya mutu pendidikan kita. Tentunya hal seperti itu dapat kita temukan jika kita menggali lebih dalam akar permasalahannya. Dan semoga jika kita mengetehui akar permasalahannya, kita dapat memperbaiki mutu pendidikan di Indonesia sehingga jadi kebih baik lagi.

Selain beberapa penyebab rendahnya kualitas pendidikan di atas, berikut ini akan dipaparkan pula secara khusus beberapa masalah yang menyebabkan rendahnya kualitas pendidikan di Indonesia. 


\section{Rendahnya Kualitas Sarana Fisik}

Untuk sarana fisik misalnya, banyak sekali sekolah dan perguruan tinggi kita yang gedungnya rusak, kepemilikan dan penggunaan media belajar rendah, buku perpustakaan tidak lengkap. Sementara laboratorium tidak standar, pemakaian teknologi informasi tidak memadai dan sebagainya. Bahkan masih banyak sekolah yang tidak memiliki gedung sendiri, tidak memiliki perpustakaan, tidak memiliki laboratorium dan sebagainya.

Data Balitbang Depdiknas (2003) menyebutkan untuk satuan SD terdapat 146.052 lembaga yang menampung 25.918.898 siswa serta memiliki 865.258 ruang kelas. Dari seluruh ruang kelas tersebut sebanyak 364.440 atau $42,12 \%$ berkondisi baik, 299.581 atau 34,62\% mengalami kerusakan ringan dan sebanyak 201.237 atau 23,26\% mengalami kerusakan berat. Kalau kondisi MI diperhitungkan angka kerusakannya lebih tinggi karena kondisi MI lebih buruk daripada SD pada umumnya. Keadaan ini juga terjadi di SMP, MTs, SMA, MA, dan SMK meskipun dengan persentase yang tidak sama.

\section{Rendahnya Kualitas Guru}

Keadaan guru di Indonesia juga amat memprihatinkan. Kebanyakan guru belum memiliki profesionalisme yang memadai untuk menjalankan tugasnya sebagaimana disebut dalam pasal 39 UU No 20/2003 yaitu merencanakan pembelajaran, melaksanakan pembelajaran, menilai hasil pembelajaran, melakukan pembimbingan, melakukan pelatihan, melakukan penelitian dan melakukan pengabdian masyarakat.

Bukan itu saja, sebagian guru di Indonesia bahkan dinyatakan tidak layak mengajar. Persentase guru menurut kelayakan mengajar dalam tahun 2002-2003 di berbagai satuan pendidikan sbb: untuk SD yang layak mengajar hanya $21,07 \%$ (negeri) dan 28,94\% (swasta), untuk SMP 54,12\% (negeri) dan 60,99\% (swasta), untuk SMA 65,29\% (negeri) dan 64,73\% (swasta), serta untuk SMK yang layak mengajar 55,49\% (negeri) dan 58,26\% (swasta).

Kelayakan mengajar itu jelas berhubungan dengan tingkat pendidikan guru itu sendiri. Data Balitbang Depdiknas (1998) menunjukkan dari sekitar 1,2 juta guru SD/MI hanya $13,8 \%$ yang berpendidikan diploma D2-Kependidikan ke atas. Selain itu, dari sekitar 680.000 guru SLTP/MTs baru 38,8\% yang berpendidikan diploma D3-Kependidikan ke atas. Di tingkat sekolah menengah, dari 337.503 guru, baru 57,8\% yang memiliki pendidikan S1 ke atas. Di tingkat pendidikan tinggi, dari 181.544 dosen, baru $18,86 \%$ yang berpendidikan S2 ke atas $(3,48 \%$ berpendidikan $\mathrm{S} 3$ ).

Walaupun guru dan pengajar bukan satu-satunya faktor penentu keberhasilan pendidikan tetapi, pengajaran merupakan titik sentral pendidikan dan kualifikasi, sebagai cermin kualitas, tenaga pengajar memberikan andil sangat besar pada 
kualitas pendidikan yang menjadi tanggung jawabnya. Kualitas guru dan pengajar yang rendah juga dipengaruhi oleh masih rendahnya tingkat kesejahteraan guru.

\section{Rendahnya Kesejahteraan Guru}

Rendahnya kesejahteraan guru mempunyai peran dalam membuat rendahnya kualitas pendidikan Indonesia. Berdasarkan survei FGII (Federasi Guru Independen Indonesia) pada pertengahan tahun 2005, idealnya seorang guru menerima gaji bulanan serbesar Rp 3 juta rupiah. Sekarang, pendapatan rata-rata guru PNS per bulan sebesar Rp 1,5 juta. guru bantu Rp, 460 ribu, dan guru honorer di sekolah swasta rata-rata Rp 10 ribu per jam. Dengan pendapatan seperti itu, terang saja, banyak guru terpaksa melakukan pekerjaan sampingan. Ada yang mengajar lagi di sekolah lain, memberi les pada sore hari, menjadi tukang ojek, pedagang mie rebus, pedagang buku/LKS, pedagang pulsa ponsel, dan sebagainya (Republika, 13 Juli, 2005).

Dengan adanya UU Guru dan Dosen, barangkali kesejahteraan guru dan dosen (PNS) agak lumayan. Pasal $10 \mathrm{UU}$ itu sudah memberikan jaminan kelayakan hidup. Di dalam pasal itu disebutkan guru dan dosen akan mendapat penghasilan yang pantas dan memadai, antara lain meliputi gaji pokok, tunjangan yang melekat pada gaji, tunjangan profesi, dan/atau tunjangan khusus serta penghasilan lain yang berkaitan dengan tugasnya. Mereka yang diangkat pemkot/pemkab bagi daerah khusus juga berhak atas rumah dinas.

Tapi, kesenjangan kesejahteraan guru swasta dan negeri menjadi masalah lain yang muncul. Di lingkungan pendidikan swasta, masalah kesejahteraan masih sulit mencapai taraf ideal. Diberitakan Pikiran Rakyat 9 Januari 2006, sebanyak 70 persen dari 403 PTS di Jawa Barat dan Banten tidak sanggup untuk menyesuaikan kesejahteraan dosen sesuai dengan amanat UU Guru dan Dosen (Pikiran Rakyat 9 Januari 2006).

\section{Rendahnya Prestasi Siswa}

Dengan keadaan yang demikian itu (rendahnya sarana fisik, kualitas guru, dan kesejahteraan guru) pencapaian prestasi siswa pun menjadi tidak memuaskan. Sebagai misal pencapaian prestasi fisika dan matematika siswa Indonesia di dunia internasional sangat rendah. Menurut Trends in Mathematic and Science Study (TIMSS) 2003 (2004), siswa Indonesia hanya berada di ranking ke-35 dari 44 negara dalam hal prestasi matematika dan di ranking ke-37 dari 44 negara dalam hal prestasi sains. Dalam hal ini prestasi siswa kita jauh di bawah siswa Malaysia dan Singapura sebagai negara tetangga yang terdekat.

Dalam hal prestasi, 15 September 2004 lalu United Nations for Development Programme (UNDP) juga telah mengumumkan hasil studi tentang kualitas manusia secara serentak di seluruh dunia melalui laporannya yang berjudul Human Development Report 2004. Di dalam laporan tahunan ini Indonesia hanya menduduki posisi ke-111 dari 177 negara. Apabila dibanding dengan negaranegara tetangga saja, posisi Indonesia berada jauh di bawahnya. 
Dalam skala internasional, menurut Laporan Bank Dunia (Greaney,1992), studi IEA (Internasional Association for the Evaluation of Educational Achievement) di Asia Timur menunjukan bahwa keterampilan membaca siswa kelas IV SD berada pada peringkat terendah. Rata-rata skor tes membaca untuk siswa SD: 75,5 (Hongkong), 74,0 (Singapura), 65,1 (Thailand), 52,6 (Filipina), dan 51,7 (Indonesia).

Anak-anak Indonesia ternyata hanya mampu menguasai 30\% dari materi bacaan dan ternyata mereka sulit sekali menjawab soal-soal berbentuk uraian yang memerlukan penalaran. Hal ini mungkin karena mereka sangat terbiasa menghafal dan mengerjakan soal pilihan ganda.

Selain itu, hasil studi The Third International Mathematic and Science StudyRepeat-TIMSS-R, 1999 (IEA, 1999) memperlihatkan bahwa, diantara 38 negara peserta, prestasi siswa SLTP kelas 2 Indonesia berada pada urutan ke-32 untuk IPA, ke-34 untuk Matematika. Dalam dunia pendidikan tinggi menurut majalah Asia Week dari 77 universitas yang disurvai di asia pasifik ternyata 4 universitas terbaik di Indonesia hanya mampu menempati peringkat ke-61, ke-68, ke-73 dan ke-75.

\section{Kurangnya Pemerataan Kesempatan Pendidikan}

Kesempatan memperoleh pendidikan masih terbatas pada tingkat Sekolah Dasar. Data Balitbang Departemen Pendidikan Nasional dan Direktorat Jenderal Binbaga Departemen Agama tahun 2000 menunjukan Angka Partisipasi Murni (APM) untuk anak usia SD pada tahun 1999 mencapai 94,4\% (28,3 juta siswa). Pencapaian APM ini termasuk kategori tinggi. Angka Partisipasi Murni Pendidikan di SLTP masih rendah yaitu 54, 8\% (9,4 juta siswa). Sementara itu layanan pendidikan usia dini masih sangat terbatas. Kegagalan pembinaan dalam usia dini nantinya tentu akan menghambat pengembangan sumber daya manusia secara keseluruhan. Oleh karena itu diperlukan kebijakan dan strategi pemerataan pendidikan yang tepat untuk mengatasi masalah ketidakmerataan tersebut.

\section{Rendahnya Relevansi Pendidikan Dengan Kebutuhan}

Hal tersebut dapat dilihat dari banyaknya lulusan yang menganggur. Data BAPPENAS (1996) yang dikumpulkan sejak tahun 1990 menunjukan angka pengangguran terbuka yang dihadapi oleh lulusan SMU sebesar 25,47\%, Diploma/S0 sebesar $27,5 \%$ dan PT sebesar $36,6 \%$, sedangkan pada periode yang sama pertumbuhan kesempatan kerja cukup tinggi untuk masing-masing tingkat pendidikan yaitu 13,4\%, 14,21\%, dan 15,07\%. Menurut data Balitbang Depdiknas 1999, setiap tahunnya sekitar 3 juta anak putus sekolah dan tidak memiliki keterampilan hidup sehingga menimbulkan masalah ketenagakerjaan tersendiri. Adanya ketidakserasian antara hasil pendidikan dan kebutuhan dunia kerja ini disebabkan kurikulum yang materinya kurang funsional terhadap keterampilan yang dibutuhkan ketika peserta didik memasuki dunia kerja. 


\section{Mahalnya Biaya Pendidikan}

Pendidikan bermutu itu mahal. Kalimat ini sering muncul untuk menjustifikasi mahalnya biaya yang harus dikeluarkan masyarakat untuk mengenyam bangku pendidikan. Mahalnya biaya pendidikan dari Taman Kanak-Kanak (TK) hingga Perguruan Tinggi (PT) membuat masyarakat miskin tidak memiliki pilihan lain kecuali tidak bersekolah. Orang miskin tidak boleh sekolah.

Untuk masuk TK dan SDN saja saat ini dibutuhkan biaya Rp 500.000, — sampai Rp 1.000.000. Bahkan ada yang memungut di atas Rp 1 juta. Masuk SLTP/SLTA bisa mencapai Rp 1 juta sampai Rp 5 juta.

Makin mahalnya biaya pendidikan sekarang ini tidak lepas dari kebijakan pemerintah yang menerapkan MBS (Manajemen Berbasis Sekolah). MBS di Indonesia pada realitanya lebih dimaknai sebagai upaya untuk melakukan mobilisasi dana. Karena itu, Komite Sekolah/Dewan Pendidikan yang merupakan organ MBS selalu disyaratkan adanya unsur pengusaha.

Asumsinya, pengusaha memiliki akses atas modal yang lebih luas. Hasilnya, setelah Komite Sekolah terbentuk, segala pungutan uang selalu berkedok, "sesuai keputusan Komite Sekolah". Namun, pada tingkat implementasinya, ia tidak transparan, karena yang dipilih menjadi pengurus dan anggota Komite Sekolah adalah orang-orang dekat dengan Kepala Sekolah. Akibatnya, Komite Sekolah hanya menjadi legitimator kebijakan Kepala Sekolah, dan MBS pun hanya menjadi legitimasi dari pelepasan tanggung jawab negara terhadap permasalahan pendidikan rakyatnya.

Kondisi ini akan lebih buruk dengan adanya RUU tentang Badan Hukum Pendidikan (RUU BHP). Berubahnya status pendidikan dari milik publik ke bentuk Badan Hukum jelas memiliki konsekuensi ekonomis dan politis amat besar. Dengan perubahan status itu Pemerintah secara mudah dapat melemparkan tanggung jawabnya atas pendidikan warganya kepada pemilik badan hukum yang sosoknya tidak jelas. Perguruan Tinggi Negeri pun berubah menjadi Badan Hukum Milik Negara (BHMN). Munculnya BHMN dan MBS adalah beberapa contoh kebijakan pendidikan yang kontroversial. BHMN sendiri berdampak pada melambungnya biaya pendidikan di beberapa Perguruan Tinggi favorit.

Privatisasi atau semakin melemahnya peran negara dalam sektor pelayanan publik tak lepas dari tekanan utang dan kebijakan untuk memastikan pembayaran utang. Utang luar negeri Indonesia sebesar 35-40 persen dari APBN setiap tahunnya merupakan faktor pendorong privatisasi pendidikan. Akibatnya, sektor yang menyerap pendanaan besar seperti pendidikan menjadi korban. Dana pendidikan terpotong hingga tinggal 8 persen (Kompas, 10/5/2005).

Dari APBN 2005 hanya 5,82\% yang dialokasikan untuk pendidikan. Bandingkan dengan dana untuk membayar hutang yang menguras $25 \%$ belanja dalam APBN (www.kau.or.id). Rencana Pemerintah memprivatisasi pendidikan dilegitimasi melalui sejumlah peraturan, seperti Undang-Undang Sistem Pendidikan Nasional, RUU Badan Hukum Pendidikan, Rancangan Peraturan Pemerintah (RPP) tentang Pendidikan Dasar dan Menengah, dan RPP tentang Wajib Belajar. Penguatan pada privatisasi pendidikan itu, misalnya, terlihat dalam Pasal 53 (1) UU No 20/2003 tentang Sistem Pendidikan Nasional (Sisdiknas). Dalam pasal itu disebutkan, 
penyelenggara dan/atau satuan pendidikan formal yang didirikan oleh Pemerintah atau masyarakat berbentuk badan hukum pendidikan.

Seperti halnya perusahaan, sekolah dibebaskan mencari modal untuk diinvestasikan dalam operasional pendidikan. Koordinator LSM Education Network for Justice (ENJ), Yanti Mukhtar (Republika, 10/5/2005) menilai bahwa dengan privatisasi pendidikan berarti Pemerintah telah melegitimasi komersialisasi pendidikan dengan menyerahkan tanggung jawab penyelenggaraan pendidikan ke pasar. Dengan begitu, nantinya sekolah memiliki otonomi untuk menentukan sendiri biaya penyelenggaraan pendidikan. Sekolah tentu saja akan mematok biaya setinggi-tingginya untuk meningkatkan dan mempertahankan mutu. Akibatnya, akses rakyat yang kurang mampu untuk menikmati pendidikan berkualitas akan terbatasi dan masyarakat semakin terkotak-kotak berdasarkan status sosial, antara yang kaya dan miskin.

Hal senada dituturkan pengamat ekonomi Revrisond Bawsir. Menurut dia, privatisasi pendidikan merupakan agenda Kapitalisme global yang telah dirancang sejak lama oleh negara-negara donor lewat Bank Dunia. Melalui Rancangan Undang-Undang Badan Hukum Pendidikan (RUU BHP), Pemerintah berencana memprivatisasi pendidikan. Semua satuan pendidikan kelak akan menjadi badan hukum pendidikan (BHP) yang wajib mencari sumber dananya sendiri. Hal ini berlaku untuk seluruh sekolah negeri, dari SD hingga perguruan tinggi.

Bagi masyarakat tertentu, beberapa PTN yang sekarang berubah status menjadi Badan Hukum Milik Negara (BHMN) itu menjadi momok. Jika alasannya bahwa pendidikan bermutu itu harus mahal, maka argumen ini hanya berlaku di Indonesia. Di Jerman, Prancis, Belanda, dan di beberapa negara berkembang lainnya, banyak perguruan tinggi yang bermutu namun biaya pendidikannya rendah. Bahkan beberapa negara ada yang menggratiskan biaya pendidikan.

Pendidikan berkualitas memang tidak mungkin murah, atau tepatnya, tidak harus murah atau gratis. Tetapi persoalannya siapa yang seharusnya membayarnya? Pemerintahlah sebenarnya yang berkewajiban untuk menjamin setiap warganya memperoleh pendidikan dan menjamin akses masyarakat bawah untuk mendapatkan pendidikan bermutu. Akan tetapi, kenyataannya Pemerintah justru ingin berkilah dari tanggung jawab. Padahal keterbatasan dana tidak dapat dijadikan alasan bagi Pemerintah untuk 'cuci tangan'.

\section{Solusi dari Permasalahan-permasalahan Pendidikan di Indonesia}

Untuk mengatasi masalah-masalah di atas, secara garis besar ada dua solusi yang dapat diberikan yaitu:

Pertama, solusi sistemik, yakni solusi dengan mengubah sistem-sistem sosial yang berkaitan dengan sistem pendidikan. Seperti diketahui sistem pendidikan sangat berkaitan dengan sistem ekonomi yang diterapkan. Sistem pendidikan di Indonesia sekarang ini, diterapkan dalam konteks sistem ekonomi kapitalisme (mazhab neoliberalisme), yang berprinsip antara lain meminimalkan peran dan tanggung jawab negara dalam urusan publik, termasuk pendanaan pendidikan.

Maka, solusi untuk masalah-masalah yang ada, khususnya yang menyangkut perihal pembiayaan -seperti rendahnya sarana fisik, kesejahteraan guru, dan 
mahalnya biaya pendidikan - berarti menuntut juga perubahan sistem ekonomi yang ada. Akan sangat kurang efektif kita menerapkan sistem pendidikan Islam dalam atmosfer sistem ekonomi kapitalis yang kejam. Maka sistem kapitalisme saat ini wajib dihentikan dan diganti dengan sistem ekonomi Islam yang menggariskan bahwa pemerintah-lah yang akan menanggung segala pembiayaan pendidikan negara.

Kedua, solusi teknis, yakni solusi yang menyangkut hal-hal teknis yang berkait langsung dengan pendidikan. Solusi ini misalnya untuk menyelesaikan masalah kualitas guru dan prestasi siswa.

Maka, solusi untuk masalah-masalah teknis dikembalikan kepada upaya-upaya praktis untuk meningkatkan kualitas sistem pendidikan. Rendahnya kualitas guru, misalnya, di samping diberi solusi peningkatan kesejahteraan, juga diberi solusi dengan membiayai guru melanjutkan ke jenjang pendidikan yang lebih tinggi, dan memberikan berbagai pelatihan untuk meningkatkan kualitas guru. Rendahnya prestasi siswa, misalnya, diberi solusi dengan meningkatkan kualitas dan kuantitas materi pelajaran, meningkatkan alat-alat peraga dan sarana-sarana pendidikan, dan sebagainya.

\section{Kesimpulan}

Kualitas pendidikan di Indonesia memang masih sangat rendah bila di bandingkan dengan kualitas pendidikan di negara-negara lain. Hal-hal yang menjadi penyebab utamanya yaitu efektifitas, efisiensi, dan standardisasi pendidikan yang masih kurang dioptimalkan. Masalah-masalah lainya yang menjadi penyebabnya yaitu:

(1). Rendahnya sarana fisik,

(2). Rendahnya kualitas guru,

(3). Rendahnya kesejahteraan guru,

(4). Rendahnya prestasi siswa,

(5). Rendahnya kesempatan pemerataan pendidikan,

(6). Rendahnya relevansi pendidikan dengan kebutuhan,

(7). Mahalnya biaya pendidikan.

Adapun solusi yang dapat diberikan dari permasalahan di atas antara lain dengan mengubah sistem-sistem sosial yang berkaitan dengan sistem pendidikan, dan meningkatkan kualitas guru serta prestasi siswa.

\section{Saran}

Perkembangan dunia di era globalisasi ini memang banyak menuntut perubahan kesistem pendidikan nasional yang lebih baik serta mampu bersaing secara sehat dalam segala bidang. Salah satu cara yang harus di lakukan bangsa Indonesia agar tidak semakin ketinggalan dengan negara-negara lain adalah dengan meningkatkan kualitas pendidikannya terlebih dahulu.

Dengan meningkatnya kualitas pendidikan berarti sumber daya manusia yang terlahir akan semakin baik mutunya dan akan mampu membawa bangsa ini bersaing secara sehat dalam segala bidang di dunia internasional. 


\section{Rujukan Inspirasi}

Ma'na, P., Agustang, A., Salusu, J., Ikhsan, A., \& Dirawan, G. D. (2015). Decision making strategic value based local wisdom Tongkonan North Toraja. Man India, 95(3), 633-639.

Upe, A., Salman, D., \& Agustang, A. (2019). The effects of the exploitation of natural resources towards risk society construction in Southeast Sulawesi Province, Indonesia. Journal of Degraded and Mining Lands Management, 6(2), 1587.

Awaru, A. O. T., Idris, R., \& Agustang, A. (2018, October). Sexual Education at High School Sinjai East. In 1st International Conference on Social Sciences (ICSS 2018). Atlantis Press.

Idris, M., Ramli, M., Agustang, A., \& Kesuma, A. I. (2015). Bureaucracy Ethics Based in Public Service Local Wisdom in Gowa. Mediterranean Journal of Social Sciences, 6(6 S4), 419-419.

Agustang, A., Pada, A. T., \& Bastiana, M. (2018, October). Social Interaction of Local Communities With Migrants and Changes in The Structure of Local Communities (Study on Plural Society in Makassar Industrial Area). In 1st International Conference on Social Sciences (ICSS 2018). Atlantis Press.

Wardah, S., Salman, D., Agustang, A., \& Fahmid, I. M. (2017). The Contestation of Organic and Non-Organic Agricultural Knowledge in Sustainable Agriculture. Mediterranean Journal of Social Sciences, 8(2), 245-245.

Agustang, A. (2018). SIMBOLIKHAJI: Studi Deskriptif Analitik pada Orang Bugis. Al-Qalam, 15(2), 317-334.

Pannyiwi, R., Agustang, A., Kasnawi, T., Pada, A. T., Yani, A., \& Syam, S. (2020). Social Network for Drug Circulation in Sidenreng Rappang Regency, Indonesia. Systematic Reviews in Pharmacy, 11(9), 575-577.

Agustang, A., \& Soelthan, A. (2015). Analysis of the Inhibiting Factors of Transparency in the Implementation of Local Governance. Mediterranean Journal of Social Sciences, 6(6 S4), 464.

Nain, U., \& Agustang, A. (2020). Analysis On The Utilization Of Village Funds In Cash For Work Program In Bulukumba Regency, South Sulawesi Indonesia. International Journal of Advanced Science and Technology, 29(7s), 2811-2818.

Azis, F., Idris, R., \& Agustang, A. (2017). Involution Fisheries: Post-Study Model of National Program in Integrated Movement at Community Fishermen's Village Development Arungkeke, Jeneponto. Mediterranean Journal of Social Sciences, 8(1), 441.

Agustang, A. D. M. P., \& Nur, H. (2020). Konflik Mahasiswa Parang Tambung Universitas Negeri Makassar. Phinisi Integration Review, 3(1), 46-54.

Rasyid, R., Agustang, A., Maru, R., Agustang, A. T. P., \& Sudjud, S. (2020). PENYULUHAN PENCEGAHAN PENYALAHGUNAAN NARKOBA DI KALANGAN PELAJAR SMP NEGERI 6 DUAMPANUA KABUPATEN PINRANG. JMM (Jurnal Masyarakat Mandiri), 4(2), 116-123. 
Rahmania, S., \& Agustang, A. (2017). PRESEPSI MAHASISWA FIK TERHADAP PENYIMPANGAN SEKSUAL LESBIAN (STUDI KASUS PADA MAHASISWA FIK UNM). JURNAL SOSIALISASI, 162-168.

Ashar, A., \& Agustang, A. (2020). Dampak Sosial Dana Desa Dalam Kesejahteraan Masyarakat Di Desa Kalola, Kecamatan Maniangpajo, Kabupaten Wajo. Jurnal Sosialisasi: Jurnal Hasil Pemikiran, Penelitian dan Pengembangan Keilmuan Sosiologi Pendidikan, (1), 19-25.

Yusuf, M., \& Agustang, A. (2020). DINAMIKA PERUBAHAN SOSIAL EKONOMI PADA MASYARAKAT KINDANG KABUPATEN BULUKUMBA. Jurnal Sosialisasi: Jurnal Hasil Pemikiran, Penelitian dan Pengembangan Keilmuan Sosiologi Pendidikan, (2), 31-37.

Fransina, M., \& Andi, A. (2019). THE ANALYSIS OF EXISTENCE OF MIGRATION IN THE CONTEXT OF BASUDARA COMMUNITY IN AMBON CITY, INDONESIA. Russian Journal of Agricultural and Socio-Economic Sciences, 94(10).

Usman, A., Agustang, A., Djalal, D., \& Annas, S. (2018, October). The Contribution Of Supporter Community In Maximizing Their Role For The Advancement Of Makassar Football Club (PSM). In 1st International Conference on Social Sciences (ICSS 2018). Atlantis Press.

Agustang, A., \& Oruh, S. Factors affecting of heropnam of mental disorders in Dadi Regional Hospital in South Sulawesi Province. Man In India, 97(11), 233-244.

Pratiwi, E. L., \& Agustang, A. (2018). PERSEPSI ORANGTUA SISWA TERHADAP TINDAKAN GURU DALAM MENDISIPLINKAN SISWA DI SMK YPKK LIMBUNG. JURNAL SOSIALISASI, 6-10.

Asri, A., Kasnawi, T., \& Agustang, A. Actors' Social Tensions on Traditional Birth Attendants and Midwife Partnerships in Childbirth Assistance (Sociology of Health Study in Bulukumba Regency).

Bahri, S., Kasnawi, T., Agustang, A., \& Adam, A. (2017). Vegetarian Community Social Movement (Analysis of Health Sociology in Makassar). The Social Sciences, 12(10), 1824-1831.

Djalante, A., Agustang, A., Tahmir, S., \& Sahabuddin, J. A Disadvantaged Tribe in Bajoe Village, Bone Regency: A Phenomenological Research on Bajo Tribe's Social Life in Bone Regency, South Sulawesi.

Rahmawati, R., \& Agustang, A. (2018). PERBANDINGAN POLA ASUH ORANG TUA SISWA BERPRESTASI DENGAN SISWA YANG TIDAK BERPRESTASI DI SMA NEGERI 2 GOWA. JURNAL SOSIALISASI, 115-119.

Agustang, A. (2018). PERAN WALI KELAS DALAM PENYELESAIAN KONFLIK ANTAR SISWA DI SMA NEGERI 1 PINRANG. JURNAL SOSIALISASI, 12-16.

Irnawaty, I., \& Agustang, A. (2019). SMARTPHONE ADDICTION PADA MAHASISWA PENDIDIKAN SOSIOLOGI FAKULTAS ILMU SOSIAL UNIVERSITAS NEGERI MAKASSAR. JURNAL SOSIALISASI, 41-46. 
Zainuddin, M., \& Agustang, A. (2019). KONTROL SOSIAL ORANGTUA TERHADAP PENGGUNAAN SMARTPHONE PADA REMAJA (STUDI DI DESA GIRING-GIRING KECAMATAN BONTONMPO KABUPATEN GOWA. JURNAL SOSIALISASI, 68-73.

Sofyan, Y., \& Agustang, A. (2018). PENERAPAN MODEL PEMBELAJARAN KOOPERATIF TIPE NHT (NUMBERED HEADS TOGETHER) TERHADAP KEAKTIFAN BELAJAR SISWA KELAS XI IPS 1 SMAN 8 MAKASSAR. JURNAL SOSIALISASI, 158-165.

Agustang, A. (2018). PENERAPAN PUNISHMENT DALAM MEMBENTUK $\begin{array}{llllll}\text { KARAKTER DISIPLIN } & \text { SISWA } & \text { DI } & \text { SMA } & \text { NEGERI } & 1\end{array}$ TAKALAR. JURNAL SOSIALISASI, 126-130.

Amiruddin, T. K., Agustang, A., \& Idris, R. (2014). RELIGIOUS CONVERSION IN MARRIED LIFE IN MAKASSAR, THE CASE OF CHRISTIANITY TO ISLAM. JOURNAL OF ACADEMIC RESEARCH, 6(6), 264.

Machmuddin, H., Agustang, A., Kahar, F., \& Bustan, N. (2015). IMPROVING THE QUALITY OF PRIMARY HEALTH SERVICES IN THE PERSPECTIVE OF PARTICIPATORY GOVERNANCE. International Journal of Academic Research, 7(1).

Agustang, A., \& Sahabuddin, J. (2020, October). MODEL KOLABORASI SOSIAL PENDIDIKAN KARAKTER DI SEKOLAH SWASTA KECAMATAN BISSAPPU KABUPATEN BANTAENG. In PROSIDING SEMINAR DAN DISKUSI PENDIDIKAN DASAR.

Astinah, A., Idris, R., \& Agustang, A. (2020). AGILE LEADERSHIP AND DIVORCE EDUCATION: STUDY ON WOMEN'S PERCEPTION. Humanities, 8(3), 323-330.

Muis, I., Agustang, A., \& Adam, A. (2020). Elderly Poverty: Social Demographic, Work Distribution, Problem Health \& Social Protection. Asian Journal of Social Sciences \& Humanities Vol, 9(1).

Agustang, A. (2020). Symbolic Violence towards Students in the Context of the Existence of the Stereotypical Frames of Lecturers and Students in the Higher Education System in Indonesia. PalArch's Journal of Archaeology of Egypt/Egyptology, 17(2), 249-258.

Asrifan, A. (2009). Using songs in teaching English language for the young learners. ParePare: unpublished.

Puasa, K., Asrifan, A., \& Chen, Y. (2017). Classroom Talk in Bilingual Class Interaction. Research in Pedagogy, 7(1), 106-121.

Nadirah, N., Tahir, M. H., \& Asrifan, A. (2019). THE ABILITY TO TRANSLATE ENGLISH PHRASES INTO INDONESIAN AND THE DIFFICULTIES FACED BY THE ELEVENTH GRADE STUDENTS OF SMAN 1 PANCARIJANG. JOURNAL OF ADVANCED ENGLISH STUDIES, 2(1), 41-46.

Apdy, A. P. R., \& Asrifan, A. (2019, April). The Chinese mime game in teaching vocabulary on EFL classroom. In PROCEEDINGS OF THE 65th TEFLIN INTERNATIONAL CONFERENCE (Vol. 65, No. 01).

Taslim, T., Asrifan, A., Chen, Y., \& Nurdania, N. R. (2019). CORRELATION BETWEEN STUDENT'S VOCABULARY MASTERY AND 
SPEAKING SKILL. JOURNAL OF ADVANCED ENGLISH STUDIES, 2(2), 65-76.

Muthmainnah, M., Asrifan, A., Al Yakin, A., \& Sahabuddin, C. (2019, April). The use of dictogloss technique on ELT classroom: An experiment study of students listening comprehension. In PROCEEDINGS OF THE 65th TEFLIN INTERNATIONAL CONFERENCE (Vol. 65, No. 01).

Mutmainnah, M., Azis, S., Maulidya, U., \& Asrifan, A. (2017). Glory Style in Mandar Song Lyrics: A study of Mandar Tribe in South Sulawesi, Indonesia. JOURNAL OF ADVANCES IN LINGUISTICS, 8(1), 12861291.

Asrifan, A., Rinantanti, Y., Tang, S., \& Nadirah, N. (2019). THE 3-DIMENSION PICTURES IN INCREASING THE STUDENTS ABILITY AND INTEREST TO WRITE DESCRIPTIVE COMPOSITION. JOURNAL OF ADVANCED ENGLISH STUDIES, 2(1), 19-30.

Asrifan, A., Nadira, N., \& Haedar, H. (2018). IMPROVING STUDENTS'READING COMPREHENSION OF DESCRIPTIVE TEXT THROUGH COLLABORATIVE MURDER. JOURNAL OF ADVANCED ENGLISH STUDIES, 1(2), 21-31.

Asrifan, A. (2015). Analysis of English Students' Learning Style in Bilingual Class. International Journal of Literature and Arts, 3(4), 34.

Farahdiba, S., \& Asrifan, A. (2016). Speaking Ability and Psychological Barriers of the Second Year Students of Hotel Department of SMKN 1 Sidenreng Kabupaten Sidrap in Speaking English. Asian EFL Journal, (89), 41.

Asrifan, A. (2012). Increasing the Students Ability to Write Descriptive Composition at SMP Negeri 13 Parepare by using the 3-Dimension Pictures.

Tang, S., Asrifan, A., Chen, Y., Haedar, H., \& Agussalim, M. (2019). THE HUMOR STORY IN TEACHING READING COMPREHENSION. JOURNAL OF ADVANCED ENGLISH STUDIES, 2(2), 77-87.

Nurwanti, N., Asrifan, A., \& Haedar, H. (2019). THE APPLICATION OF COOPERATIVE LEARNING: JIGSAW II TECHNIQUE IN IMPROVING STUDENTS'READING COMPREHENSION OF EXPOSITORY TEXT. JOURNAL OF ADVANCED ENGLISH STUDIES, 2(1), 31-40.

Asrifan, A. (2016). The Effectiveness of Think-Pair-Share Technique in Improving Studentsâ€TM Speaking Ability and Interest. English Literature and Language Review, 2(3), 24-35.

Asrifan, A., Muthmainnah, M., Al-Yakin, A., Sahabuddin, C., \& Haedar, H. (2018). THE CAUSE-EFFECT TECHNIQUE IN TEACHING RECOUNT WRITING. JOURNAL OF ADVANCED ENGLISH STUDIES, 1(2), 63-72.

Asrifan, A., Vargheese, K. J., Syamsu, T., \& Amir, M. (2020). ESP COURSE DESIGN: THE NEED ANALYSIS ON TOURISM DEPARTMENT IN INDONESIA VOCATIONAL HIGH SCHOOLS. JOURNAL OF ADVANCED ENGLISH STUDIES, 3(2), 69-77. 
Asrifan, A., Ghofur, A., \& Azizah, N. (2020). Cheating Behavior in EFL Classroom (A Case Study at Elementary School in Sidenreng Rappang Regency). OKARA: Jurnal Bahasa dan Sastra, 14(2), 279-297.

Nadirah, N., Asrifan, A., Vargheese, K. J., \& Haedar, H. (2020). INTERACTIVE MULTIMEDIA IN EFL CLASSROOM: A STUDY OF TEACHING READING COMPREHENSION AT JUNIOR HIGH SCHOOL IN INDONESIA. JOURNAL OF ADVANCED ENGLISH STUDIES, 3(2), 131-145.

Muthmainnah, A. R., Atmowardoyo, H., Salija, K., \& Asrifan, A. (2020). Literary Work as Teaching Materials: A Study of Students and Lecturers Needs Analysis. Solid State Technology, 63(5), 394-407.

Tilome, A. A., Agustang, A., Jasruddin, M. S., \& Asrifan, A. (2020). Social Exchange of Political Elites in the Regional Leader Election of Gorontalo Province, Indonesia. Solid State Technology, 63(5), 521-531.

Pacinongi, A., \& Asrifan, A. (2020). Bimbingan Pengawas Berkelanjutan dalam Mewujudkan Pendidikan Karakter Bangsa dalam Kegiatan Belajar Mengajar Penjaskes. Celebes Education Review, 2(1), 1-7.

Gunawan, G., \& Asrifan, A. (2020). Penerapan Kerja Kelompok Kegiatan MGMP Guru Ekonomi dalam Menyusun RPP untuk Meningkatkan Kompetensi Pedagogik. Celebes Education Review, 2(1), 31-36.

Yusuf, I., \& Asrifan, A. PENINGKATAN AKTIVITAS KOLABORASI PEMBELAJARAN FISIKA MELALUI PENDEKATAN STEM DENGAN PURWARUPA PADA SISWA KELAS XI IPA SMAN 5 YOGYAKARTA. Editorial Team, 32.

Al Yakin, A., Sahabuddin, C., Rahayu, A., Fitrah, N., \& Arifin, M. (2020). Political Celebrification and Electability: A Study of Political Phenomena Imaging in Election Polewali Mandar District, West Sulawesi, Indonesia. Solid State Technology, 63(5), 632-646.

Junaedah, S. B. T., \& Ahmad, M. A. (2020). The Outdoor Learning Modules Based on Traditional Games in Improving Prosocial Behaviour of Early Childhood. International Education Studies, 13(10).

Octaberlina, L. R., \& Muslimin, A. I. (2020). Efl students perspective towards online learning barriers and alternatives using moodle/google classroom during covid-19 pandemic. International Journal of Higher Education, 9(6), 1-9.

Octaberlina, L. R., \& Anggarini, I. F. (2020). Teaching vocabulary through picture cards in Islamic Elementary School: a case study in Nida Suksa School, Thailand. Jurnal Madrasah, 13(1), 26-38.

Octaberlina, L. R. (2016). Plagiarism in English language theses in Indonesia. Jurnal Ilmu Pendidikan, 14(3).

Octaberlina, L. R., \& Anggarini, I. F. (2020). Teaching vocabulary through picture cards in Islamic Elementary School: a case study in Nida Suksa School, Thailand. Jurnal Madrasah, 13(1), 26-38.

Asrifan, A., Zita, C. T., Vargheese, K. J., Syamsu, T., \& Amir, M. (2020). THE EFFECTS OF CALL (COMPUTER ASSISTED LANGUAGE LEARNING) TOWARD THE STUDENTS'ENGLISH 
ACHIEVEMENT AND ATTITUDE. JOURNAL OF ADVANCED ENGLISH STUDIES, 3(2), 94-106.

Asrifan, A. (2021). ACADEMIC WRITING. LawArXiv. January, 2. https://doi.org/10.31228/osf.io/x2s7e

Asrifan, A. (2020). TUTORIAL PENGGUNAAN QUIZIZZ (www. quizizz. com) PADA PEMBELAJARAN. https://doi.org/10.31219/osf.io/kqnza

Asrifan, A. (2021). Abd Ghofur.“. THE USE OF READING CIRCLES IN INCREASING STUDENTS SPEAKING ABILITY AT THE ELEVENTH GRADE SMK SEGERI, 1. https://doi.org/10.31219/osf.io/8vjxy

Asrifan, A. (2020). Pandemic, Humanity and Education. https://doi.org/10.31219/osf.io/q2gpk

Asrifan, A. (2021). USING CAT AND MOUSE GAME TO IMPROVE STUDENT'S SPEAKING ABILITY AT THE ELEVENTH GRADE OF MA YMPI RAPPANG. https://doi.org/10.31219/osf.io/phtvn

Asrifan, A., \& Ghofur, A. (2021). THE USE OF READING CIRCLES IN INCREASING STUDENTS SPEAKING ABILITY AT THE ELEVENTH GRADE SMK NEGERI 1 PANCARIJANG. https://doi.org/10.31219/osf.io/8vjxy

Asrifan, A. (2021). Book Review: Halliday. 1989. Spoken and Written Language. Oxford University Press. https://doi.org/10.31219/osf.io/ej8tb

Asrifan, A., \& Ghofur, A. (2021). TALK, ACTION, SILENCE, INTERRUPTION AND THEIR IMPLICATIONS IN BUGINESE SOCIETY (SOPPENG REGENCY). https://doi.org/10.31219/osf.io/pv3ku

Asrifan, A. (2020). PENILAIAN BERBASIS ANDROID MENGGUNAKAN APLIKASI PLICKERS. https://doi.org/10.31219/osf.io/htreq

Sapulette, A. A., Agustang, A., \& Syukur, M. Actor Construction in the Frame of Diversity to Achieve Social Harmony in the Life of Tamilouw Village Society Seram Island-Maluku.

Amiruddin, T. K., Agustang, A., \& Idris, R. (2014). RELIGIOUS CONVERSION IN MARRIED LIFE IN MAKASSAR, THE CASE OF CHRISTIANITY TO ISLAM. JOURNAL OF ACADEMIC RESEARCH, 6(6), 264.

Machmuddin, H., Agustang, A., Kahar, F., \& Bustan, N. (2015). IMPROVING THE QUALITY OF PRIMARY HEALTH SERVICES IN THE PERSPECTIVE OF PARTICIPATORY GOVERNANCE. International Journal of Academic Research, 7(1).

Agustang, A., \& Sahabuddin, J. (2020, October). MODEL KOLABORASI SOSIAL PENDIDIKAN KARAKTER DI SEKOLAH SWASTA KECAMATAN BISSAPPU KABUPATEN BANTAENG. In PROSIDING SEMINAR DAN DISKUSI PENDIDIKAN DASAR.

Mutiara, I. A., Agustang, A., Adam, A., Upe, A., \& Equatora, M. A. (2020). The dynamics of prostitutes lives in metropolitan cities. Journal of Critical Reviews. https://doi. org/10.31838/jcr, 7, 165. 
Haulussy, R. H., Najamuddin, I. R., \& Agustang, A. D. M. P. (2020). The sustainability of the Sasi Lola tradition and customary law (Case study in Masawoy Maluku, Indonesia). Intl J Sci Technol Res, 9(2), 5193-5195.

Agustang, A. (2020). Symbolic Violence towards Students in the Context of the Existence of the Stereotypical Frames of Lecturers and Students in the Higher Education System in Indonesia. PalArch's Journal of Archaeology of Egypt/Egyptology, 17(2), 249-258.

Agustang, A. (2015). Dasar-Dasar Filsafat Penelitian Untuk Pengembangan Ilmu.

Agustang, A. T. P. Muh. Said, dan Rusman Rasyid. 2015. Perkembangan Peran Jender Dalam Prespektif Teori Androgini, 1-8.

Rasyid, R., Agustang, A., Agustang, A. T. P., Bastiana, B., \& Najamuddin, N. Analisis Faktor Yang Mempengaruhi Status Kemiskinan Rumah Tangga Pada Wilayah Central Bussiness District (CBD) di Kota Makassar. Majalah Geografi Indonesia, 34(1), 43-52.

Asmi, A. S., Kasnawi, M. T., Agustang, A., \& Yani, A. (2020). Sociocultural Transformation in Efforts to Reduce Mortality of Infants in Bone Regency, Indonesia. Systematic Reviews in Pharmacy, 11(10), 762-765.

Agustang, A. (2020, October). Social Actions of Galla Actors in the Kaemba Maros Traditional Village Community Sulawesi Selatan. In 3rd International Conference on Social Sciences (ICSS 2020) (pp. 748-753). Atlantis Press.

Agustang, A. (2020). The Symbolic Violence Towards Private School Students Through The Frame Stereotype In Bantaeng District Of Indonesia. Prosiding ICoISSE, 1(1), 578-588.

Ariani $^{1}$, A. I., Agustang, A., Adam, A., \& Alimsyah, S. (2020). INSTITUTIONAL FAILURES IN THE WORLD OF EDUCATION IN SCHOOLS FOR CHILDREN VICTIMS OF PARENTS. Asian Journal of Social Sciences \& Humanities Vol, 9, 2. 